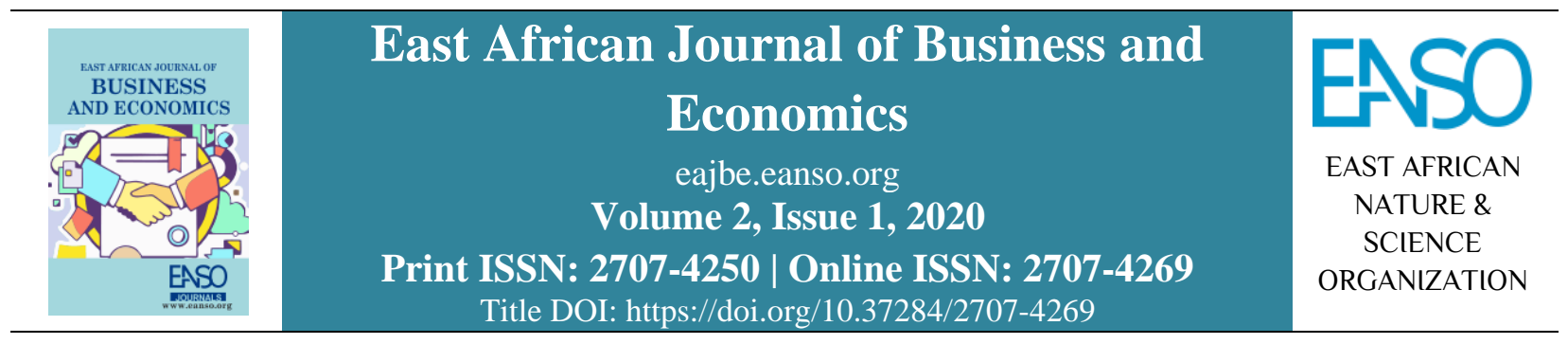

Original Article

\title{
Brand Image as a Determinant of Customer Loyalty in Selected Nairobi Hotels.
}

\author{
Lydia Aluoch Akunja ${ }^{1 *}$ \\ ${ }^{1}$ School of Tourism, Hospitality and Events Management, Moi University, P. O. Box 3900, Eldoret, Kenya. \\ *Correspondence email: 1.akunja@gmail.com. \\ *ORCID: https://orcid.org/0000-0002-6963-0401
}

\section{Article DOI: https://doi.org/10.37284/eajbe.2.1.168}

Date Published: ABSTRACT

17 June 2020 Loyalty among customers is a major purpose for firms seeking lasting connections with their patrons. Creating and sustaining an acceptable product Keywords: image with consumers is vital for sustaining a business in today's spirited markets. The relationship between brand image and customer loyalty in hotels is blurred. Additionally, scholarly works associated with brand image and

Customer Loyalty, Brand Image,

Branding,

Hospitality,

Hotel. loyalty in the hotel and hospitality sector in Kenya is inadequate, hence the study gap. The study purpose sought to investigate the effects of brand image on customer loyalty in Kenyan hotels It employed an explanatory research design. From a target population of 1,191 customers, 253 formed the sample size while six marketing executives were interviewed for key information. Purposive, stratified, and systematic random sampling methods were used. Instruments for data collection included self-administered questionnaires and interview schedules. Data was reduced using factor analysis and simple regression conducted to test study hypotheses. Findings indicated that brand image $(\mathrm{t}=12.747, \mathrm{p}<.001)$ considerably affected loyalty among customers. The study concludes that advancement in the brand image likely results in enhanced loyalty. The study, therefore, recommends that hospitality operations should focus on tangible dimensions of their units, promote staff-guest interactions and increase measures to enhance their corporate image to remain competitive while retaining existing customers and attracting new ones.

\section{APA CITATION}

Akunja, L. (2020). Effects of Brand Image on Customer Loyalty in Selected Hotels in Nairobi, Kenya. East African Journal of Business and Economics, 2(1), 29-42. https://doi.org/10.37284/eajbe.2.1.168

\section{CHICAGO CITATION}

Akunja, Lydia. 2020. "Effects of Brand Image on Customer Loyalty in Selected Hotels in Nairobi, Kenya". East African Journal of Business and Economics 2 (1), 29-42. https://doi.org/10.37284/eajbe.2.1.168.

\section{HARVARD CITATION}


Akunja, L. (2020) "Effects of Brand Image on Customer Loyalty in Selected Hotels in Nairobi, Kenya", East African Journal of Business and Economics, 2(1), pp. 29-42. doi: 10.37284/eajbe.2.1.168.

\section{IEEE CITATION}

L. Akunja, "Effects of Brand Image on Customer Loyalty in Selected Hotels in Nairobi, Kenya", EAJBE, vol. 2, no. 1, pp. 2942, Jun. 2020.

\section{MLA CITATION}

Akunja, Lydia. "Effects of Brand Image on Customer Loyalty in Selected Hotels in Nairobi, Kenya". East African Journal of Business and Economics, Vol. 2, no. 1, Jun. 2020, pp. 29-42, doi:10.37284/eajbe.2.1.168

\section{INTRODUCTION}

Several justifications are cited for the development of branding in hotel and hospitality businesses. According to Sangster et al. (2001), Brand owners is prescribed as the capability to attach premium prices beyond rival chain hotels and independent properties, attaining a favourable segment of the market against rivals and retaining customers through loyalty to brands thereby reduce marketing costs. O'Neill and Mattila (2004) emphasise that brands with superior visitor satisfaction attain better revenues per guest room and realize increased room revenues than lesser satisfying brands.

Brand loyalty is exhibited by the emotional dedication to frequent a favoured product or service, leading to repetitive same brand purchase, despite unpredicted influences and marketing activities having the ability to cause behaviour change (Oliver, 1999). Harris and Goode (2004) agreed with Oliver's approach that a multicomponent representation was an inclusive assessment of brand loyalty. Devoted consumers' exhibit limited intentions for extended information search for alternative suppliers, hence reducing brand switching possibilities (Gounaris \& Stathakopoulos, 2004). Bowen and Shoemaker (2003) researching in a luxury hotel affirmed that devoted customers claimed they purchased other hotel offerings (like laundry services and meals) more regularly at hotels where they were loyal compared to units where there was less loyalty.

According to authors, Daun \& Klinger, (2006); Kandampully \& Hu, (2007); Shoemaker and Lewis, (1999), the hotel industry is increasingly competitive and reaching the maturity stage. Hospitality services are therefore commoditized (Cai \& Hobson, 2004; Mattila, 2006) and differences between the services availed by same star ratings shrink (Bowen \& Shoemaker, 2003; Peterson \& Iyer, 2006). Frequent approaches to counter these trends are coming up with loyalty programs as suggested by Mattila, (2006) and Palmer et al., (2000). But, Palmer et al., (2000) warn that these are prone to imitation and duplication. Establishments that adopt these programs early likely enjoy periods of cutthroat competition and its returns. However, these are diminished when the competition imitates them. McMullan and Gilmore (2003) emphasize that guests also alter their exploration to comprise of competitive price and attractive rewards. Without an intimate bond with brands, loyalty driven programs have minimal influence on characteristics of the brand and managerial implications

Brand name including what it represents makes for one of the most important assets for hospitality businesses. Properly handled branding enhances the competitiveness of a firm. A number of chain hotels possess brand identifiers recognizable by their clients. Kotler et al., (2010) posit that away from the visible factors other underlying attributes influence the achievement of service outlets since differentiation is created by outstanding brands among competitors. Visualization and understanding of intangible products among customers are created by strong brands. Reducing perceived risks is complicated prior to purchase (Berry, 2000). However, the link between the variables is neither straight forward nor simple. 
Further, there exists limited literature related to brand image and its effects on customer loyalty especially in the Kenyan hotels hence the need for this study.

\section{LITERATURE REVIEW}

\section{The Concept of Customer Loyalty}

Loyalty in service markets is dimensional because one customer demonstrates different loyalty standards towards a service at different times. Loyal customers purchase regularly across products, engage in referrals and are resistant to competitors' pull. (Griffin \& Herres, 2002). Loyalty among customers is key for firms seeking customer relationships. According to Prus and Brandt (1995), loyal patrons engage in repeat purchase and recommend the provider. Loyal customers stick with organizations longer, purchase more and often have increased lifelong value (Stone \& Woodcock, 1995). The ultimate return for an organization is loyal customers. Buying more, for longer and telling others is loyalty (Goodwright, 2005).

Brand loyalty is exhibited by repeated purchasing behaviour and brand sensitivity. Premium guests experiencing familiar brands and attaching significance to it is said to have customer-based brand equity and is loyal (Odin et al., 2001). They are less likely to switch solely because of prices and tend to purchase frequently than those who are not loyal. (Bowen \& Shoemaker, 1998).

Hospitality establishments expose their products to more customers so as to generate and boost brandloyal customers who are likely to purchase their offerings if and when available. Loyalty starts with customer awareness of the product (Aaker, 1991). The greater the product awareness, the higher the possibility of purchase. High consciousness about a brand and positivity amplifies the likelihood of patronage, hence greater loyalty and diminished vulnerability to opponents' marketing activities (Keller, 1993). Initial efforts to maintain customer brand loyalty is building and sustaining agreeable image. Authors Andreassen and Lindestad (1997) carefully note, that buyer loyalty may be "extrinsic prompting for both current and future buyers" and "might sway brand image". Overall a hotel brand represents a connection with visitors. That connection is built on brand knowledge, use, and evaluation of experiences and begins relationships anchored on continued usage. Eventually, brands represent experiences with providers. Augmented competition forces hotels to increasingly provide memorable experiences to guest away from simple service provision (Gilmore and Pine 2002).

Recognizing the influence branding has on business value is important. However, alternative benefits derived from branding including customer fulfilment and reliability must be fully considered in order to assess brands' value in entirety (O'Neill \& Xiao, 2006). Guest satisfaction is driven by among others, Immaculate rooms, maintenance levels, friendly employees and sound product knowledge (Oh, 1999; Mattila \& O’Neill, 2003), coupled with physical attributes (Mattila, 1999; Mattila \& O'Neill, 2003). Statistically, hotel names exhibiting high satisfaction levels achieve notable Average Daily Rates (ADRs) as well as a significant percentage increase in their ADRs over time (O’Neill and Mattila 2004).

Brand loyalty measures the connection customers have towards a brand (Aaker, 1991). Brand loyalty provides several benefits, like repetitive purchases, word of mouth marketing of the brand, and a way to remain competitive to other retailers (Lau \& Lee, 2009). Identifying the development of the consumer self in relation to a given product or brand can help marketers connect or reconnect their brand to consumers (Tucker, 1964). Also, retaining customers often call for fewer resources compared to attracting new customers (Knox \& Walker, 2001).

Reputations of brands can be developed through adverts and public relations as well as influenced by 
product quality and performance. Positive reputations result in trust as a result of met expectations. Conversely, negative repute may result in suspicion towards a brand and awareness of possible flaws (Lau \& Lee, 2009). Consumer trust in a brand may also be influence by the company behind the brand. This is beneficial when introducing new products in the market, hence a higher likelihood of purchase. Consumers tend to trust companies perceived as working in their best interests and exhibit compassion. Integrity also enhances trust among patrons. Exercising integrity involves keeping promises, exercising ethics and honesty (Lau \& Lee, 2009). Brand competency involves solving customer problems and meeting their needs. These are gauged from customer feedback. Once convinced of the ability to solve their problems, consumers will likely rely on such brands (Lau \& Lee, 2009).

Willingness to pay more among consumers is influenced by the ability of a brand to offer unique value not provided by alternatives (Pessemier, 1959; Jacoby \& Chestnut, 1978; Reichheld, 1996). This arises from the trust and performance of the brand when the customer uses it. Repeated purchase of the brand increases into a market share (Assael, 1998). Favourable attitudes towards brands lead to wiliness towards premium payments among consumers (Keller, 1993).

\section{The Concept of Brand Image}

Keller (1993) defined brand image as the perception of a brand related to the brand linked to the memory of the consumer. Perception of the brand image is built on associations and attitudes and reflects brand equity (Srivastava and Shocker, 1991; Keller, 1993; Park \& Srinivasan, 1994; Aaker, 1996; Agarwal \& Rao, 1996; Feldwick, 1996). The brand image comes from the total experiences of consumers and the quality of service offered (Aydin and O"zer, 2005). The hotel industry is mature and competitive; hence brand image acts as a vital alternative for differentiation (Kim \& Kim, 2005).

According to Mazanec (1995), image significantly determines marketing actions. However, its definition is not agreed upon by most authors. One broadly used concept put forward by Keller (1993) states: it is the perceptions held about a brand reflected by associations in memories of consumers. Other definitions emphasize emotional, symbolic, significance, communications, and personification aspect (Dobni \& Zinkhan, 1990; Aaker, 1996; Gronroos, 2000). Four important parameters including impressions held by consumers, basically subjective and a perceptual experience formed through individual interpretation, which may be emotional or rational but not supported by the technical, functional or physical concerns of the product offered. Rather, influenced, affected and moulded by marketing efforts, variations in contexts and individual characteristics and perceptions of reality assigned more importance than the actual reality (Dobni \& Zinkhan 1990).

Referring to the consumer emotional frame, several factors are presented as affecting the image of the brand. Kandampully and $\mathrm{Hu}$ (2007) present an image as a concept that represents much more than the sum of the realistic attributes of an organization. Others like Gronroos (2000) and later Lee et al., (2008) further posit that a customers' mind is shaped by their genuine experiences with the products as well as promotional strategies employed. Furthermore, it is fashioned by associations with the business, state, and channels of distribution, individual, or occurrences (Park et al., 1996). Essentially, the image of a brand is determined by relations among accurate and emotional essentials of an organization used to generate the patrons' impressions of a brand (Dobni \& Zinkhan, 1990; Keaveney \& Hunt, 1992). Later on, Aaker (1996) maintained that client's experiences were paramount. Brand distinctiveness describes distinct attributes of a product of value to 
the customer. These, in turn, affect perceptions and how a brand is perceived and its associations. Furthermore, these attributes are distinguishing tangible and intangible features of a product that gives value to the user (Kotler \& Amstrong, 2004).

Comments, complaints and suggestions conveyed by family and friends make up informal spoken information (Hogg et al., 2006). Spoken word can further communicate to present and potential consumers. The positive or negative message between consumers leads to positive or negative word-of-mouth, resulting in the image of the brand (Gronroos, 2002). There is a tendency to believe informal information from direct conversations as opposed to information from formal channels. The more affirmative information consumers receive about a firm or a product, the higher the probability of contact or purchase (Hogg et al., 2006). Conflict in the message in the word-of-mouth communication and the message in an advert could cause the message in the advertisement to generally attract minimal importance (Gronroos, 2002).

Advertising builds and sustains an alluring appearance of a company while enticing purchase and creating loyalty (Martensson, 2008). It should be swaying and persuade those who watch to purchase. It can further, stick to memories if it is broadcasted frequently. Most importantly, a commercial of communication should present a unique attribute or benefit for differentiation to attract the target market (Hogg et al., 2006). Effective advertisement gets viewer attention, creates accurate brand awareness, and increases or strengthens brand inclination. Commercials are advantageous since they create awareness and build attractive associations around the brand (Martensson, 2008).

Oliver (1999) argues that loyalty goes beyond the superiority of products and customer fulfilment; it involves having customers willing and able to defend a brand. An organization that is not able to grow, maintain and retain brand uniqueness and perceived equity of its brand inhibit allegiance to the brand. Consequently, having a well-built and positive brand image strengthens the apparent worth and helps in the advancement of loyalty towards brands (Oliver, 1999; Cretu \& Brodie, 2007). Scholars Fredericks and Salter (1995) advance image as a component of value customers seek alongside value for money, excellence in service and innovativeness. Brand image plays an integral part in the delivery of service in hotels where contending offerings are thought to be virtually impossible to tell apart in terms of presentation, value, accessibility and availability (Schuiling \& Kapferer, 2004). Regrettably, a large part of the inquiries on the image of brands has focused on tangibles and retail businesses (Bloemer et al., 1998). On the contrary, fewer researches have incorporated image as a determinant of loyalty (Chitty et al., 2007; Lai et al., 2009). Therefore, including brand image when examining the services is necessary.

\section{METHODOLOGY}

The research was undertaken in Nairobi, Kenya. The explanatory research design was used. The total target population for the study was 1,191 respondents and a sample size of 253. Six marketing managers from the establishments were also targeted as key informers. Purposive, stratified, and systematic random sampling techniques were used. Tools of data collection were questionnaires and interview schedules. Reliability was measured using Cronbach's Alpha at a level of $0.7 \%$. Descriptive and inferential statistics were used for data analysis. Factor analysis assisted to minimize the number of items on the variables for ease of analysis, interpretation, presentation, and discussion. Simple regression checked the effects of the brand image against customer loyalty. The regression model was given as $\mathrm{Y}_{\mathrm{i}}=\beta_{0+} \beta_{\mathrm{i}} \mathrm{X}_{\mathrm{i}}+\mu$ 
East African Journal of Business and Economics, Volume 2, Issue 1, 2020

Article DOI: https://doi.org/10.37284/eajbe.2.1.168

\section{RESULTS AND DISCUSSION}

To evaluate the degree to which brand image is a determinant of customer loyalty, various indicators were used. These were analyzed on a 5-point Likert Scale. Table 1 shows the descriptive statistics representing the respondents' levels of agreement with the statements measuring brand image. About $85.8 \%$ of the customers strongly agreed that hotels had a good reputation. In reference to the statement on feeling special when staying at the hotel, a total of $98.9 \%$ responded as strongly agree and agree on which indicated that the hotels focused on providing a pleasurable experience for their guests. Out of the 253 respondents, $66.1 \%$ strongly agreed the hotels were unique while $65.0 \%$ indicated the hotels were comfortable. A cumulative percentage of $77.1 \%$ strongly agreed and agreed the hotels were luxurious for their categories. $57.9 \%$ of the customers strongly agreed that the hotels suited their needs. $94.5 \%$ of the respondents agreed they would engage in positive word of mouth advertisement about the hotels. In reference to the effectiveness of the advertisement methods employed by the hotels, $83.6 \%$ agreed they were effective. $98.9 \%$ of the respondents agreed that the hotels had good public relations. Table 1 shows that the measures of the brand image were found to be determinants of customer loyalty with mean statistics of between 4.2 and 4.8 and a standard deviation of between 0.37 and 0.95 .

Table 1: Measures of Brand Image

\begin{tabular}{|c|c|c|c|c|c|c|c|c|c|c|c|c|}
\hline \multirow[t]{3}{*}{ Statement } & \multicolumn{10}{|c|}{ Measurement } & \multicolumn{2}{|c|}{ Statistics } \\
\hline & \multicolumn{2}{|c|}{ SD } & \multicolumn{2}{|l|}{ D } & \multicolumn{2}{|l|}{$\mathbf{N}$} & \multicolumn{2}{|l|}{$\mathbf{A}$} & \multicolumn{2}{|l|}{ SA } & \multirow[b]{2}{*}{$\mathbf{M}$} & \multirow[b]{2}{*}{ SD } \\
\hline & $\mathbf{f}$ & $\%$ & f & $\%$ & $\mathbf{f}$ & $\%$ & $\mathbf{f}$ & $\%$ & f & $\%$ & & \\
\hline The hotel has a good reputation & - & - & - & - & 1 & 0.5 & 25 & 13.7 & 157 & 85.8 & 4.85 & 0.37 \\
\hline $\begin{array}{l}\text { I get a sense of being special at the } \\
\text { hotel }\end{array}$ & - & - & - & - & 2 & 1.1 & 66 & 36.1 & 115 & 62.8 & 4.62 & 0.51 \\
\hline This hotel is unique & - & - & 1 & 0.5 & 24 & 13.1 & 37 & 20.2 & 121 & 66.1 & 4.52 & 0.74 \\
\hline The hotel offers comfort & - & - & - & - & 16 & 8.7 & 48 & 26.2 & 119 & 65 & 4.56 & 0.65 \\
\hline The hotel is lavish for its category & 4 & 2.2 & 2 & 1.1 & 36 & 19.7 & 47 & 25.7 & 94 & 51.4 & 4.23 & 0.95 \\
\hline I feel the hotel suits my needs & - & - & - & - & 8 & 4.4 & 69 & 37.7 & 106 & 57.9 & 4.54 & 0.58 \\
\hline $\begin{array}{l}\text { I would engage in positive } \mathrm{W}-\mathrm{O}-\mathrm{M} \\
\text { communication concerning the hotel }\end{array}$ & - & - & - & - & 10 & 5.5 & 76 & 41.5 & 97 & 53 & 4.48 & 0.60 \\
\hline $\begin{array}{l}\text { The advertising methods employed } \\
\text { by this hotel are effective }\end{array}$ & - & - & 9 & 4.9 & 21 & 11.5 & 64 & 35 & 89 & 48.6 & 4.27 & 0.85 \\
\hline The hotel has good public relations & - & - & - & - & 2 & 1.1 & 78 & 42.6 & 103 & 56.3 & 4.55 & 0.52 \\
\hline
\end{tabular}

Brand image denoted as $\mathrm{X}_{1}$ with nine indicators had a Cronbach Alpha of 0.848 whereas the dependent variable Customer Loyalty (Y) with twelve indicators had a Cronbach Alpha of 0.926. The KMO measure of sampling accuracy indicates a $\mathrm{KMO}=0.678$ which is above the minimum 0.5 . This implies the sample was sufficient for the variables analysed. Bartlett's Test of Sphericity that tested the adequacy of the correlation matrix yielded a value of 1081.052 and an associated level of significance smaller than 0.001 , therefore the findings imply that factor analysis was suitable for the study hence a relationship between the variables. 
East African Journal of Business and Economics, Volume 2, Issue 1, 2020

Article DOI: https://doi.org/10.37284/eajbe.2.1.168

Table 2: KMO and Bartlett's Test of Brand Image

\begin{tabular}{lll} 
Kaiser-Meyer-Olkin Measure of Sampling Adequacy. & .678 \\
Bartlett's Test of Sphericity & Approx. Chi-Square & 1081.052 \\
& Df & 36 \\
& Sig. & .000 \\
\hline
\end{tabular}

Although nine factors were computed for brand image, some of the factors were not useful in representing the list of variables. Using the condition of retaining only factors with eigenvalues values of 1 or greater, the first 3 factors were retained for rotation. These 3 factors accounted for $49.04 \%, 15.12 \%$, and $13.23 \%$ of the total variance respectively. This is nearly $77.38 \%$ of the total variance attributed to the three factors. The residual factors account for $22.62 \%$ of the variance (

Table 3). Thus, a model with three factors was sufficient to represent the data.

Table 3: Total Variance Explained of Brand Image

\begin{tabular}{lccccccccc}
\hline Component & \multicolumn{3}{c}{ Initial Eigenvalues } & \multicolumn{3}{c}{$\begin{array}{c}\text { Extraction Sums of Squared } \\
\text { Loadings }\end{array}$} & \multicolumn{3}{c}{$\begin{array}{c}\text { Rotation Sums of Squared } \\
\text { Loadings }\end{array}$} \\
\cline { 2 - 13 } & Total & $\begin{array}{c}\text { \% of } \\
\text { Variance }\end{array}$ & $\begin{array}{c}\text { Cumulative } \\
\text { \% }\end{array}$ & Total & $\begin{array}{c}\text { \% of } \\
\text { Variance }\end{array}$ & $\begin{array}{c}\text { Cumulative } \\
\%\end{array}$ & Total & $\begin{array}{c}\text { \% of } \\
\text { Variance }\end{array}$ & $\begin{array}{c}\text { Cumulative } \\
\text { \% }\end{array}$ \\
\hline Uniqueness & 4.414 & 49.040 & 49.040 & 4.414 & 49.040 & 49.040 & 3.236 & 35.955 & 35.955 \\
Reputation & 1.360 & 15.115 & 64.155 & 1.360 & 15.115 & 64.155 & 1.978 & 21.980 & 57.936 \\
Advertisement & 1.190 & 13.226 & 77.381 & 1.190 & 13.226 & 77.381 & 1.750 & 19.446 & 77.381 \\
\hline
\end{tabular}

Extraction Method: Principal Component Analysis.

a. 3 components extracted

Table 4 shows rotated component matrix representing three factors after Varimax rotation. The cluster of items in each aspect and their phrasing offer the indication as to the connotation of the factors. These three workings describe totals of variables grouped into each one of the three major components namely: brand uniqueness, reputation, and advertisement. The interactions converged in 4 iterations. The components rotated using Varimax Criterion for reducing multicollinearity and hence account for $100 \%$ of the variation.

Table 4: Rotated Component Matrix (a) of Brand Image

\begin{tabular}{lccc}
\hline Statement & Uniqueness & $\begin{array}{c}\text { Component } \\
\text { Reputation }\end{array}$ & Advertisement \\
\hline Comfortable hotel & .882 & & \\
Luxurious for its category & .881 & \\
Hotel is unique & .816 & \\
Suits the needs of the customers & .713 & \\
Helpful verbal evidence about the hotel & .576 & \\
Good reputation & & .859 \\
\hline
\end{tabular}


East African Journal of Business and Economics, Volume 2, Issue 1, 2020

Article DOI: https://doi.org/10.37284/eajbe.2.1.168

\begin{tabular}{lccc}
\hline Statement & Uniqueness & $\begin{array}{c}\text { Component } \\
\text { Reputation }\end{array}$ & Advertisement \\
\hline Feel special when staying at the hotel & & .751 & \\
Effective advertisement method employed & & & .895 \\
Good public relations exist & & & .714 \\
\hline $\begin{array}{l}\text { Extraction Method: Principal Component } \\
\text { Normalization. }\end{array}$ & & & \\
a Rotation converged in 4 iterations. & & & \\
\hline
\end{tabular}

\section{Customer Loyalty and Brand Image}

A regression analysis of $\mathrm{Y}$ (customer loyalty) against $\mathrm{X}_{1}$ (brand image), was done and the regression model was: $\mathrm{Y}_{\mathrm{i}}=\beta_{\mathrm{o}}+\beta_{1} \mathrm{X}_{1}+\mu-\mathrm{Y}_{\mathrm{i}}=-$ $0.125+0.978 \mathrm{X}_{1}+\mu$.

Table 5: Coefficients of $Y$ on $X_{1}$

\begin{tabular}{|c|c|c|c|c|c|c|c|c|c|c|c|c|}
\hline \multirow[t]{2}{*}{ Model } & \multicolumn{2}{|c|}{$\begin{array}{c}\text { Unstandardized } \\
\text { Coeff. }\end{array}$} & \multirow{2}{*}{$\begin{array}{c}\text { Standardized } \\
\text { Coeff. } \\
\text { Beta }\end{array}$} & \multirow[t]{2}{*}{$\mathbf{T}$} & \multirow[t]{2}{*}{ Sig. } & \multicolumn{2}{|c|}{$\mathbf{9 5 \%}$ CI for B } & \multicolumn{3}{|c|}{ Correlations } & \multicolumn{2}{|c|}{$\begin{array}{l}\text { Collinearity } \\
\text { Statistics }\end{array}$} \\
\hline & $\mathbf{B}$ & $\begin{array}{l}\text { Std. } \\
\text { Error }\end{array}$ & & & & $\begin{array}{l}\text { Lower } \\
\text { Bound }\end{array}$ & $\begin{array}{l}\text { Upper } \\
\text { Bound }\end{array}$ & $\begin{array}{l}\text { Zero- } \\
\text { order }\end{array}$ & Partial & Part & $\begin{array}{l}\text { Toler } \\
\text { Ance }\end{array}$ & VIF \\
\hline (Constant) & -.125 & .348 & & -.358 & .721 & -.811 & .562 & & & & & \\
\hline $\begin{array}{l}\text { BRAND } \\
\text { IMAGE }\end{array}$ & .978 & .077 & .688 & 12.747 & .000 & .827 & 1.130 & .688 & .688 & .688 & 1.000 & 1.000 \\
\hline
\end{tabular}

From the model, there exists a positive association between $\mathrm{Y}_{\mathrm{i}}$ (customer loyalty) and the $\left(\mathrm{X}_{1}\right)$, resulting from the positive coefficient of the variable; $0.978 . \quad \hat{\beta}=0.978$ is the sample parameter approximation of the population parameter $\beta$. It indicates that when the brand image improves by one-unit percentage, customer loyalty is enhanced by $97.8 \%$. It follows then that unit advancement in brand image in terms of brand uniqueness, good reputation, and effective advertisement will improve customer loyalty by $97.8 \%$ among the sampled customers.

The $95 \%$ confidence interval for the assessment of $\beta$ ranged between 0.827 and 1.130 for the lower and upper bound respectively. The true population considerations lie in the range on 95 occasions out of one hundred in the parameters estimated. The standard error of estimation stood at 0.077 . This is a minimal value in relation to the regression coefficient implying a dependable prediction of $\beta$.
The standard error estimates the extent to which the regression coefficient varies between samples of the same size from a similar population; that is, if one was to take multiple samples of a similar size from the exact population and calculate the regression equation, this would present an approximation of how much the regression coefficient would vary from a sample to sample

$\mathrm{H}_{0} 1$ : Brand image does not significantly affect customer loyalty

The sample estimate $\hat{\beta} 4=0.978$ was established to be statistically significant at a $1 \%$ level and 181 degrees of freedom with $\mathrm{t}_{1}=12.747$. Therefore, brand image significantly determines customer loyalty among the sampled clientele.

These results reject the hypothesis that brand image does not affect customer loyalty in selected hotels in Nairobi. This is because the calculated value of 
$\mathrm{t}_{4}=12.747$ was greater than the critical value of $\mathrm{t}_{\alpha}$ $=2.960$.

\section{Correlation}

A simple correlation analysis established the degree of relationship between $(\mathrm{Y})$ and $\left(\mathrm{X}_{1}\right)$. The study had hypothesized that there was no significant effect of brand image on customer loyalty.
From Table 6., there exists a positive association between the dependent and the independent variables. The correlation coefficient was 0.688 . The positive sign of correlation indicates the variables likely move in similar directions, to be precise; they tend to increase or decrease together. The coefficient was established to be statistically significant at the $1 \%$ level of significance.

Table 6: Correlation of Customer Loyalty and Brand Image

\begin{tabular}{llll}
\hline & & Customer Loyalty $(\mathbf{Y})$ & Brand Image $\left(\mathbf{X}_{4}\right)$ \\
\hline Pearson Correlation & Customer Loyalty $(\mathrm{Y})$ & 1.000 & .688 \\
& Brand Image $\left(\mathrm{X}_{1)}\right.$ & .688 & 1.000 \\
Sig. (1 tailed) & Customer Loyalty $(\mathrm{Y})$ &. & .000 \\
& Brand Image $\left(\mathrm{X}_{1}\right)$ & .000 &. \\
\hline
\end{tabular}

Model Summary of Customer Loyalty on Brand Image

The coefficient of determination $\left(\mathrm{R}^{2}\right)$ is by definition the percentage/ proportion of sum variation in the dependent variable (Y) explained by regressing $\mathrm{Y}$ on $\mathrm{X}$ (Koutsoyiannis, 1993). $\mathrm{R}^{2}$ was 0.473 . This value of $\mathrm{R}^{2}=0.473$, deducing that regression of $\mathrm{Y}$ on $\mathrm{X}_{1}$, explains $47.3 \%$ of the variations in $\mathrm{Y} . \mathrm{R}^{2}$ of $47.3 \%$ implies the model is significant in the study of customer loyalty of hotel customers and that the model captured an essential variable. The variation results $(100-47.3) \%$ can be attributed to factors included in the error term.

Table 7: Model Summary of Y on X1

\begin{tabular}{|c|c|c|c|c|c|c|c|c|c|c|}
\hline \multirow[t]{2}{*}{ Model } & \multirow[t]{2}{*}{$\mathbf{R}$} & \multirow[t]{2}{*}{$\mathbf{R}^{2}$} & \multirow[t]{2}{*}{$\begin{array}{c}\text { Adjusted } \\
\qquad \mathbf{R}^{\mathbf{2}}\end{array}$} & \multirow[t]{2}{*}{$\begin{array}{l}\text { Std. } \\
\text { Err }\end{array}$} & \multicolumn{5}{|c|}{ Change Statistics } & \multirow[t]{2}{*}{$\begin{array}{l}\text { Durbin } \\
\text { Watson }\end{array}$} \\
\hline & & & & & $\begin{array}{c}\mathbf{R}^{2} \\
\text { Change }\end{array}$ & $\begin{array}{c}\text { F } \\
\text { Change }\end{array}$ & df1 & df2 & $\begin{array}{c}\text { Sig. F } \\
\text { Change }\end{array}$ & \\
\hline 1 & $.688^{\mathrm{a}}$ & 0.473 & 0.47 & 0.46187 & 0.473 & 162.493 & 1 & 181 & 0 & 2.275 \\
\hline \multicolumn{11}{|c|}{ a Predictors: (Constant), Brand image } \\
\hline \multicolumn{11}{|c|}{ b Dependent Variable: Customer Loyalty } \\
\hline
\end{tabular}

The variable brand image $\left(\mathrm{X}_{1}\right)$ constituted three sub-components: brand uniqueness, good reputation, and effective advertisement. The correlation was 0.688 .

\section{DISCUSSION OF RESULTS AND CONCLUSION}

A memorable customer service experience is created to the customer owing to the 
establishments' image and the totality of the service experience. The customers agreed that the hotels had a good reputation which created a positive image of the establishment and their offerings in the opinion of patrons. A section of the guests attributed this to the fact that they had been referred to the units by others who had stayed there and had a "superb" experience. These study findings are in agreement with Gronross (2002) who posits that positive or negative communiqué between consumers' leads to positive or negative word-ofmouth among consumers, whose outcome may be the positive or negative image towards a brand. Customers are inclined to consider individual, informal information obtained from those they interact with directly and believe it to be more reliable than the information received through prescribed channels, such as advertising. The majority of the patrons felt special when staying at the hotels with some saying "We were offered VIP treatment regardless of the real VIPs staying here". This was coupled with guests getting personalized services from friendly and helpful staff which indicated that the hotels focused on providing a pleasurable experience for their guests regardless of the composition of their clientele at any given time.

Brand uniqueness describes the uniqueness of a product that is of significance to the consumer. These attributes thereby affect the consumer's perception of a product and ultimately how consumers distinguish a brand and what associations they create about the brand. Furthermore, these product characteristics are distinguishing tangible and intangible features that give value to the user (Kotler \& Amstrong, 2004). The findings of the study support these statements as customers strongly agreed the hotel was unique. This was probably because the hotels sought to provide that distinct Kenyan magic in their décor and ambience, which made each unit different from another even in the case of those that belong to groups or chain companies. This is also consistent with Kim and Kim (2005) who advocates that in an established and cutthroat environment, like in the hospitality industry, brand image plays an imperative role as an option towards product differentiation.

Superb standard accommodation, quiet environment, beautiful gardens, and cleanliness were some of the descriptions used by guests to signify their evaluation of the comfort of the establishments stayed at supported by a majority who strongly agreed. Although an impressive number of the respondents supposed the statement that the hotels were luxurious for their category based on the facilities and level of service, a few strongly disagreed. This was almost certainly due to dissatisfaction with room sizes and bed quality, noise, and costs of services.

94.5\% of the respondents agreed they would employ positive spoken communication about the hotels. They held they would tell others about the hotel and recommend it to friends and relatives. It, therefore, pays for hoteliers to focus on satisfying their guests to rip off the benefits of the free advertisement from positive referrals and avoid negative publicity.

Viewer attention, accurate brand awareness, creating, increasing and strong brand fondness is created by effective advertising. Strong associations that are attractive and creation of awareness about a brand are a result of commercials (Martensson, 2008). The advertisement methods employed by the hotels were effective as they adequately provided needed information to potential patrons. The study findings are consistent with the statement above. However, some customers disagreed with this and the reasons were indicated as the inability of some methods to adequately provide much-needed information and therefore negatively influencing their loyalty.

Gronroos (2000) states that the image of a brand is a significant variable in the advancement of loyalty towards particular brands. Earlier, Oliver (1999) 
appreciated loyalty as going beyond product dominance and offering satisfaction. Additionally, it is about creating brand defenders. If a hotel is unable to build up support, and sustain its uniqueness together with apparent brand justice, advancement towards loyalty is limited. The study found that the measures were adequate indicators of brand image and the variable significantly determined loyalty of customers thus informing the rejection of the stated hypothesis.

Brand image significantly affected customer loyalty. A providers' ability to create and maintain associations in a customers' recollection fundamentally determines their loyalty. These arguments inform the conclusion that brand image is a considerable determinant of customer loyalty. Also, it is evident that the factors influencing loyalty toward a brand are varied and therefore hospitality operators must understand their clients to develop services designed not only to appeal to them but also to distinguish the provider from competitors.

\section{REFERENCES}

Aaker, D. A. (1991). Managing brand equity. New York, NY: Free Press.

Aaker, D. A. (1996). Building a strong brand: The Free Press.

Agarwal, M. K., \& Rao, V. R. (1996). An empirical comparison of consumer-based measures of brand equity. Marketing letters, 7(3), 237-247.

Andreassen, T. W., Lindestad, B., \& Barometer, C. S. (1997). Customer Loyalty and Complex Services: The Impact of Corporate Image on Quality, Customer Satisfaction. Management, 8(4), 7-23.

Assael, H. (1998). Consumer behaviour and marketing action. Cincinnati, OH: SouthWestern.
Aydin, S., \& Özer, G. (2005). The analysis of antecedents of customer loyalty in the Turkish mobile telecommunication market. European Journal of Marketing, 39(7/8), 910-25.

Berry, L. L. (2000). Cultivating service brand equity. Journal of the Academy of Marketing Science, 28(1), 128-137.

Bloemer, J., Ruyter, K., \& Peeters, P. (1998). Investigating drivers of bank loyalty: The complex relationship between image, service quality, and satisfaction. The International Journal of Bank Marketing, 16(7), 276-286.

Bowen, J. T., \& Shoemaker, S. (2003). Loyalty: A strategic commitment. The Cornell Hotel and Restaurant Administration Quarterly, 44(5-6), 31-46.

Cai, L. A., \& Hobson, J. P. (2004). Making hotel brands work in a competitive environment. Journal of Vacation Marketing, 10(3), 197-208.

Chitty, B., Ward, S., \& Chua, C. (20017). An application of the ECSI model as a predictor of satisfaction and loyalty for backpacker hostels. Marketing Intelligence \& Planning, 25, 563-580.

Cretu, A. E., \& Brodie, R. J. (2007). The influence of brand image and company reputation where manufacturers market to small firms: A customer value perspective. Industrial Marketing Management, 36(2), 230-240.

Daun, W., \& Klinger, R. (2006). Delivering the message. International Journal of Contemporary Hospitality Management, 18(3), 246-252.

Dobni, D., \& Zinkhan, G. M. (1990). In search of brand image: A foundation analysis. Advances in Consumer Research, 17, 110119. 
Feldwick, P. (1996). What is brand equity anyway, and how do you measure it? Market Research Society. Journal., 38(2), 1-17.

Fredericks, J. O., \& Salt, J. M. (1995). Beyond customer satisfaction. Management Review, 29-32.

Gilmore, J. H., and J. (2002). Pine. Differentiating hospitality operations via experiences. Cornell Hotel and Restaurant Administration Quarterly 43 (3): 87-96.

Gounaris, S., \& Stathakopoulos, V. (2004). Antecedents and consequences of brand loyalty: An empirical study. Journal of Brand Management, 11(4), 283-306.

Griffin, J., \& Herres, R. T. (2002). Customer loyalty: How to earn it, how to keep it. San Francisco, CA: Jossey-Bass.

Gronroos, C. (1984). A service quality model and its marketing implications. European Journal of Marketing, 18(4), 36-44.

Gronroos, C. (Ed.). (2000). Service management and marketing ( $2^{\text {nd }}$ ed.): John Wiley and Son.

Harris, L. C., \& Goode, M. M. (2004). The four levels of loyalty and the pivotal role of trust: a study of online service dynamics. Journal of retailing, 80(2), 139158.

Hogg, M., Askegaard, S., Bamossy, G., \& Solomon, M. (2006). Consumer behaviour: a European perspective. Madrid: PrenticeHall.

Jacoby, J., \& Chestnut, R. W. (1978). Brand loyalty: Measurement and management. New York Wiley.

Kandampully, J., \& Hu, H. H. (2007). Do hoteliers need to manage image to retain loyal customers? International Journal of
Contemporary Hospitality Management, 19(6), 435-443.

Keaveney, S. M., \& Hunt, K. A. (1992). Conceptualization and operationalization of retail store image: A case of rival middle-level theories. Academy of Marketing Science Journal, 20(2), 165175.

Keiningham, T. L., Aksoy, L., Cooil, B., \& Andreassen, T. W. (2008). Linking customer loyalty to growth. MIT Sloan Management Review, 49(4), 51-57.

Keller, K. (1993). Conceptualizing, measuring, and managing customer-based brand equity. Journal of Marketing, 57(1), 1-22.

Kim, H., \& Kim, W. (2005). The relationship between brand equity and firms' performance in luxury hotels and chain restaurants. Tourism Management, 26(4), 549-560.

Knox, S., \& Walker, D. (2001). Measuring and managing brand loyalty. Journal of Strategic Marketing, 9(2), 111-128.

Kotler, P., \& Armstrong, G. (2004). Principles of marketing (Vol. 10th). Upper Saddle River, NJ Prentice-Hall.

Kotler, P., Bowen, J. T., \& Makens, J. C. (2010). Marketing for hospitality and tourism $\left(5^{\text {th }}\right.$ ed.). Prentice-Hall.

Lai, F., Griffin, M., \& Babin, B. J. (2009). How quality, value, image, and satisfaction create loyalty at a Chinese telecom. Journal of Business Research, (62), 980-986.

Lau, G. T., \& Lee, S. H. (2009). Consumers' trust in a brand and the link to brand loyalty. Journal of Market - Focused Management, 4(4), 341.

Lee, M., Knight, D., \& Kim, Y. (2008). Brand analysis of a US global brand in 
comparison with domestic brands in Mexico, Korea, and Japan. The Journal of Product and Brand Management, 17, 163174.

Mattila, A. S. (1999). The role of culture and purchase motivation in service encounter evaluations. Journal of Services Marketing, 13(4/5), 376.

Mattila, A. S. (2006). How effective commitment boosts guest loyalty (and promotes frequent-guest programs). Cornell Hotel and restaurant administration quarterly, 47(2), 174-181.

Mazanec, J. A. (1995). Positioning analysis with self-organizing maps. Cornell Hotel and Restaurant Administration Quarterly, 36(6), 80-95.

McMullan, R., \& Gilmore, A. (2003). The conceptual development of customer loyalty measurement: A proposed scale. Journal of Targeting, Measurement, and Analysis for Marketing, 11(3), 230-243.

O’Neill, J. W., \& Mattila, A. S. (2004). Hotel branding strategy: Its relationship to guest satisfaction and room revenue. Journal of Hospitality \& Tourism Research, 28(2), 156-165.

O'Neill, J. W., \& Xiao, Q. (2006). The role of brand affiliation in hotel market value. Cornell Hotel and Restaurant Administration Quarterly, 47, 210-223.

Odin, Y., Odin, N., \& Valette-Florence, P. (2001). Conceptual and operational aspects of brand loyalty: An empirical investigation. Journal of Business Research, 53(2), 75-84.

Oh, H. (1999). Service quality, customer satisfaction, and customer value: A holistic perspective. International Journal of Hospitality Management, 18(1), 67-82.
Oliver, R. L. (1999). Whence consumer loyalty? Journal of Marketing, 63(4_suppl1), 33-44.

Park, C. W., Jun, S. Y., \& Shocker, A. D. (1996). Composite branding alliances: An investigation of extension and feedback effects. Journal of Marketing Research, 33(4), 453-466.

Park, C. S. \& Srinivasan, V. (1996). A surveybased method for measuring and understanding brand equity and its extendibility. Journal of Marketing Research, 31(May), 271-88.

Pessemier, E. (1959). A new way to determine buying decisions. Journal of Marketing, 24(2), 41-46.

Peterson, M., \& Iyer, D. S. (2006). Gauging an industry standard of attitudinal loyalty for vacation lodging in the USA. Journal of Vacation Marketing, 12(2), 107-118.

Prus, A., and Brandt, D. R. (1995). Understanding your customers. American Demographics, Jul (1995), 10-13.

Reichheld, F. F. (1996). The Loyalty Effect: The Hidden Force Behind Growth. Profits and Lasting Value. Boston: Harvard Business School Press.

Sangster, A., Wolton, J., \& McKenney, S. (2001). The international hotel industrycorporate strategies and global opportunities. London: Travel and Tourism Intelligence.

Schuiling, I., \& Kapferer, J. (2004). Real differences between local and international brands: Strategic implications for international marketers. Journal of International Marketing, 12(4), 97-112.

Shoemaker, S., \& Lewis, R. C. (1999). Customer loyalty: the future of hospitality 
East African Journal of Business and Economics, Volume 2, Issue 1, 2020

Article DOI: https://doi.org/10.37284/eajbe.2.1.168

marketing. International journal of

hospitality management, 18(4), 345-370.

Srivastava, R. K. \& Shocker, A. D. (1991).

Brand equity: a perspective on its meaning and measurement, Working Paper No. 91124. Cambridge, MA: Marketing Science Institute.

Stone, M. \& Woodcock, N. (1995). Relationship Marketing. London, UK: Kogan Page.

Tucker, W. T. (1964). The development of brand loyalty. Journal of Marketing Research, 1(000003), 3235. 